\title{
TINJAUAN SISTEM PENYIMPANAN BERKAS REKAM MEDIS DI RUMAH SAKIT UMUM PUSAT H ADAM MALIK TAHUN 2019
}

\author{
${ }^{1}$ Zulham Andi Ritonga; ${ }^{2 \cdot}$ Faradila Maya Sari \\ 1. Dosen Prodi D-III Perekam Dan Infokes Imelda, Jalan Bilal Nomor 52 Medan; 2.Alumni D-III Perekam \\ Dan Infokes Imelda
}

E-mail: ${ }^{1 .}$ zulhamandi16@gmail.com

2. faradilakoto@gmail.com

\begin{abstract}
ABSTRAK
Pelaksanaan rekam medis dimulai dari penerimaan pasien sampai dengan pengambilan kembali berkas rekam medis. Salah satu bagian yang sangat berperan yaitu penyimpanan berkas rekam medis yang baik dan bebas dari akses informasi terhadap orang-orang yang tidak mempunyai kepentingan pada pelayanan kesehatan. Desain penelitian yang digunakan adalah kualitatif dengan menggunakan pedoman wawancara dan observasi. Lokasi penelitian dilakukan di Rumah Sakit Umum Pusat (RSUP) H Adam Malik Medan. Informan dalam penelitian ini adalah seluruh petugas penyimpanan berkas rekam medis di RSUP H Adam Malik sebanyak 9 orang. Hasil penelitian menunjukkan bahwa sistem penjajaran berkas rekam medis yang diterapkan di RSUP H Adam Malik Medan menggunakan sistem angka akhir. Penyimpanan menurut lokasi menggunakan sentralisasi yaitu berkas rekam medis rawat jalan dan rawat inap dijadikan satu file. Adanya prosedur penyimpananan, penjajaran, peminjaman, pengambilan dan penomoran berkas rekam medis. Dari hasil wawancara dan observasi faktor yang memengaruhi penyimpanan berkas rekam medis adalah petugas penyimpanan, prosedur dan fasilitas yang mendukung dalam penyimpanan berkas rekam medis.
\end{abstract}

Kata kunci: Rekam Medis, Sistem penyimpanan.

\section{PENDAHULUAN}

Rekam medis merupakan keterangan baik yang tertulis maupun yang terekam tentang identitas, anamnese, penentuan fisik laboratorium, diagnosa segala pelayanan dan tindakan medik yang diberikan kepada pasien dan pengobatan baik yang dirawat inap, rawat jalan maupun yang mendapat pelayanan gawat darurat (Permenkes RI, 2008). Rekam medis merupakan kumpulan fakta tentang kehidupan seseorang dari riwayat penyakit termasuk keadaan sakit, pengobatan saat ini dan saat lampau yang ditulis oleh para praktisi kesehatan dalam upaya mereka memberikan pelayanan kesehatan kepada pasien (Hatta, 2013).

Penyelenggaraan rekam medis dimulai saat diterimanya pasien di rumah sakit, kegiatan pencatatan data medis pasien selama mendapatkan pelayanan di rumah sakit dan penanganan berkas rekam medis yang meliputi penyelenggaraan penyimpanan serta pengeluaran berkas dari tempat penyimpanan untuk melayani permintaan atau peminjaman untuk keperluan lainnya.

Salah satu kegiatan yang dilaksanakan dalam rekam medis adalah pengelolaan sistem penyimpanan berkas. Menurut (Budi, 2011), pengelolaan penyimpanan berkas rekam medis sangat penting untuk dilakukan dalam suatu institusi pelayanan kesehatan karena dapat mempermudah dan mempercepat ditemukan kembali berkas rekam medis yang disimpan dalam rak penyimpanan, mudah dalam pengambilan dari tempat penyimpanan, mudah pengembaliannya, melindungi berkas rekam medis dari bahaya pencurian, bahaya kerusakan fisik, kimiawi dan biologi. 
Unit penyimpanan digunakan sebagai tempat penyimpanan, penyedia dan pelindung berkas rekam medis terhadap kerahasiaan. Penyimpanan rekam medis dilaksanakan oleh petugas yang ditunjuk oleh pimpinan sarana pelayanan kesehatan. Penyimpanan sangatlah penting untuk melihat riwayat penyakit pasien dan kunjungan ulang pasien, oleh sebab itu cara penyimpanan berkas rekam medis harus diatur dengan baik.

Penyimpanan berkas rekam medis yang baik merupakan satu kunci keberhasilan manajemen dari suatu pelayanan. Hal ini harus didukung dengan sistem yang baik, sumber daya manusia yang bermutu dan prosedur kerja dan sasaran serta fasilitas penyimpanan yang memadai. Penyimpanan berkas rekam medis dilaksanakan untuk menunjang pelayanan pasien rawat jalan maupun rawat inap. Sistem penyimpanan berkas rekam medis melalui prosedur yang sistematis akan memudahkan petugas dalam penemuan kembali secara cepat dan tepat bila sewaktu-waktu dibutuhkan.

Faktanya sistem penyimpanan di rumah sakit belum terlaksana dengan baik, di bagian rak penyimpanan berkas rekam medis masih sering terjadi kesalahan seperti kesalahan penempatan berkas rekam medis, salah simpan berkas rekam medis dan tidak ditemukannya berkas rekam medis di rak penyimpanan.

Hal ini bisa diamati dari ruang penyimpanan yang ada di rumah sakit tersebut dan dari rak penyimpanannya. Jika dalam ruang penyimpanan rekam medis itu terlalu sempit dan penyediaan rak file tidak sesuai dengan banyaknya rekam medis yang ada, maka penyimpanan rekam medis menjadi padat yang menyebabkan rekam medis dan sampul pelindung menjadi rusak, rak penyimpanan rekam medis terlihat kurang rapi dan jika ada pengambilan kembali rekam medis menyebabkan pelayanan sedikit lama karena pada sampul pelindung rekam medis banyak nomor rekam medis yang hilang atau rusak sehingga akan berdampak terhadap mutu pelayanan rekam medis di rumah sakit (Depkes RI, 2006).
Berkas rekam medis berisi data individual yang bersifat rahasia, setiap lembar formulir berkas rekam medis harus dilindungi dengan cara dimasukkan ke dalam folder atau map, setiap folder berisi data dan informasi hasil pelayanan yang diperoleh pasien secara individu. Penyimpanan berkas rekam medis bertujuan; (1) Mempermudah dan mempercepat ditemukan kembali berkas rekam medis yang disimpan dalam rak penyimpanan, (2) Mudah mengambil dari tempat penyimpanan, (3) Mudah pengembaliannya, (4) Melindungi berkas rekam medis dari bahaya pencurian, kerusakan fisik, kimiawi dan biologi. Diperlukan sistem penyimpanan dengan mempertimbangkan jenis sarana atau peralatan yang digunakan, tersedianya tenaga ahli dan kondisi organisasi. Syarat berkas rekam medis dapat disimpan yaitu apabila pengisian data hasil pelayanan pada lembar formulir rekam medis telah terisi dengan lengkap sehingga riwayat penyakit seorang pasien tersusun secara kronologis (Budi, 2011).

Sistem penyimpanan berdasarkan lokasi penyimpanannya terdiri dari 2 (dua) cara yaitu sentralisasi dan desentralisasi. Penyimpanan desentralisasi adalah terjadi pemisahan antara rekam medis rawat inap dan rawat jalan. Rekam medis disimpan di suatu tempat penyimpanan yang berbeda. Sedangkan sentralisasi yaitu penggabungan penyimpanan antara rekam medis rawat jalan dan rawat inap. Penjajaran adalah sistem penataan rekam medis dalam suatu sekuens yang khusus agar rujukan dan pengambilan kembali (retrieve) menjadi mudah dan cepat. Terdapat 3 (tiga) cara dalam sistem penjajaran rekam medis yaitu sistem alphabetical, alphanumerical, dan numerical. Sedangkan berdasarkan cara penjajarannya dibagi menjadi 3 (tiga) yaitu; Straight Numerical filing (SNF) atau sistem nomor langsung, Midle Digit Filing (MDF) atau sistem angka tengah, Terminal Digit Filing (TDF) atau sistem angka akhir (Budi, 2011).

Pada waktu penjajaran rekam medis, petugas rekam medis harus melihat angka pertama dan membawa rekam tersebut ke rak penyimpanan. Pada kelompok angka 
pertama rekam medis di sesuaikan urutan letaknya menurut angka kedua, kemudian rekam medis di simpan di dalam urutan sesuai dengan kelompok angka ketiga. Sehingga dalam setiap kelompok penyimpanan angka ketiga yang selalu berbeda (Depkes RI, 2006).

Penelitian oleh Agustina (2008), penyimpanan berkas rekam medis yang baik merupakan salah satu kunci keberhasilan atau kebaikan manajemen rekam medis dari suatu pelayanan kesehatan, tentunya jika didukung dengan sistem yang baik. Sumber daya mausia yang bermutu dan prosedur atau tata kerja yang baik serta sarana atau fasilitas penyimpanan yang memadai.

Sesuai dengan penelitian yang dilakukan oleh Utari (2012), kegiatan menyimpan rekam medis merupakan usaha melindungi rekam medis dari kerusakan fisik dan isi dari rekam medis itu sendiri. Rekam medis harus di simpan dan dirawat dengan baik karena rekam medis merupakan harta benda rumah sakit yang sangat berharga.

Selanjutnya penelitian oleh Tarigan (2013) di RSUP. H. Adam Malik Medan, terjadi salah simpan berkas rekam medis dengan persentase sebesar $10 \%$. Selanjutnya penelitian oleh Anggraeni (2013) di Rumah Sakit Bhayangkara Semarang, terjadinya salah simpan berkas rekam medis dengan persentase sebesar $20 \%$.

Rumah Sakit Umum Pusat (RSUP) H Adam Malik Medan merupakan sebuah rumah sakit umum dan pendidikan yang dimiliki pemerintah pusat tipe A dengan Akreditasi Internasional (JCI). Jumlah kunjungan pasien rawat jalan pada tahun 2016 sebanyak 511.598 pasien, tahun 2017 sebanyak 542.394 pasien dan tahun 2018 sebanyak 543.406 pasien. Sedangkan jumlah kunjungan rawat inap pada tahun 2016 sebanyak 41.994 pasien, tahun 2017 sebanyak 127.630 pasien dan tahun 2018 sebanyak 46.800 pasien. Jumlah petugas rekam medis sebanyak 89 orang dimana diantaranya terdapat 9 orang di bagian penyimpanan dengan tingkat pendidikan SLTA/sederajat.

Berdasarkan survey awal, diketahui bahwa masih terjadi kesalahan letak (missfile) pada berkas rekam medis. Hal ini karena kurangnya pemanfaatan tracer (petunjuk keluar) dan buku kendali sebagai alat untuk serah terima berkas rekam medis agar jelas siapa yang meminjam dan menerimanya sehingga tidak diketahui apakah rekam medis tersebut masih diluar ruangan atau sudah dikembalikan, sehingga berkas rekam medis tidak ditemukan saat pencarian menimbulkan keterlambatan dalam pelayanan pasien.

Sistem penyimpanan rekam medis menggunakan sentralisasi, yaitu suatu sistem penyimpanan dengan cara menyatukan berkas rekam medis rawat jalan, rawat darurat dan rawat inap kedalam satu folder tempat penyimpanan. Sehingga penyimpanan berkas rekam medis tidak terpisah antara dokumen berkas rekam medis rawat inap, rawat jalan maupun rawat darurat.

Terjadinya salah dalam penyimpanan berkas rekam medis yang tidak sesuai dengan nomor rekam medis yaitu sebanyak $20 \%$. Terdapat penomoran ganda sebanyak $10 \%$. Bertambahnya jumlah pasien mengakibatkan ruang dan rak penyimpanan menjadi terbatas dimana jumlah rak yang ada sebanyak 70 rak dengan jenis terbuka. Dalam 1 rak terdapat 1000 berkas rekam medis yang dijajarkan. Sering terjadi tidak ditemukannya berkas medis di dalam rak penyimpanan. Sistem pemyimpanan adalah suatu sistem dalam menyimpan berkas rekam medis di suatu ruangan demi terjaganya keamanan dan kerahasiaannya sehingga dapat digunakan suatu saat nanti. Sistem penjajaran rekam medis di RSUP H Adam Malik menggunakan sistem angka akhir (Terminal Digit Filling System).

\section{Perumusan Masalah}

Bagaimana prosedur pelaksanaan dan fasilitas penyimpanana berkas rekam medis Rumah Sakit Umum Pusat H Adam Malik?

\section{Tujuan Penelitian}

Penelitian ini bertujuan untuk Untuk mengetahui prosedur pelaksanaan dan fasilitas penyimpanan berkas rekam medis Rumah Sakit Umum Pusat H Adam Malik. 


\section{Manfaat Penelitian}

1. Bagi Rumah Sakit

Menghasilkan informasi tentang sistem penyimpanan berkas rekam medis Rumah Sakit Umum Pusat H Adam Malik dan masukan kepada direktur rumah sakit dalam memperbaiki sarana dan prasarana penyimpanan berkas rekam medis.

2. Bagi Intitusi Pendidikan

Menjadi bahan referensi untuk meningkatkan penyelenggaraan pendidikan perekam dan informasi kesehatan yaitu dalam sistem penyimpanan berkas rekam medis di rumah sakit.

3. Peneliti

Menjadi bahan informasi, edukasi dan perbandingan bagi peneliti sejenis selanjutnya yang berhubungan dengan masalah penelitian ini.

\section{METODE}

\section{Jenis Penelitian}

Jenis penelitian adalah penelitian kualitatif yang bertujuan untuk mengetahui bagaimana sistem penyimpanan berkas rekam medis di Rumah Sakit Umum Pusat H. Adam Malik Tahun 2019.

\section{Lokasi dan Waktu Penelitian}

Penelitian ini dilakukan di Rumah Sakit Umum Pusat H. Adam Malik Medan pada bulan Februari sampai dengan Agustus 2019.

\section{Subjek Penelitian}

Subjek penelitian adalah keseluruhan subjek atau objek penelitian yang akan diteliti yaitu petugas, prosedur dan fasilitas yang ada.

\section{Informan Penelitian}

Informan penelitian ini adalah seluruh petugas rekam medis di bagian penyimpanan sebanyak 9 orang untuk menggali informasi melalui wawancara tentang sistem penyimpanan berkas rekam medis Rumah Sakit Umum Pusat H. Adam Malik.
Jenis dan Metode Pengumpulan Data

Adapun sumber data yang digunakan yaitu:

1. Data primer

Data primer diperoleh langsung dari petugas rekam medis melalui wawancara dan dari hasil observasi.

2. Data sekunder

Data sekunder adalah data yang sudah ada yaitu profil rumah sakit, kebijakan dan SOP yang ada di rumah sakit, penelitian sebelumnya serta dokumentasi lainnya.

\section{Instrumen Penelitian}

Instrumen penelitian yang digunakan dalam penelitian ini yaitu pedoman wawancara dan lembar check list untuk observasi.

\section{Teknik Analisa Data}

Analisis data dilakukan secara deskriptif melalui reduksi data, penyajian dan penarikan kesimpulan, sehingga diperoleh gambaran yang jelas tentang penyelenggaraan penyimpanan berkas rekam medis di Rumah Sakit Umum Pusat H. Adam Malik Medan.

\section{HASIL}

\section{Karakteristik Petugas Penyimpanan}

Analisis univariat dilakukan dengan tujuan mendapatkan gambaran deskriptif dari variabel petugas penyimpanan, prosedur, fasilitas dan sistem penyimpanan berkas rekam medis di Rumah Sakit Umum Pusat H Adam Malik Tahun 2019.

Berdasarkan hasil penelitian, sebagian besar responden berada dalam kategori umur > 37 tahun sebanyak 7 responden $(77,8 \%)$, sebagian kecil berumur $<37$ tahun sebanyak 2 orang $(22,2 \%)$. Berdasarkan Jenis kelamin, sebagian besar responden berjenis kelamin perempuan sebanyak 8 orang $(88,9 \%)$, sebagian kecil laki-laki sebanyak 1 orang $(11,1 \%)$. Berdasarkan status perkawinan sebagian besar responden kawin sebanyak 8 orang $(88,9 \%)$ dan sebagian kecil belum kawin sebanyak 1 orang $(11,1 \%)$. 
Hasil penelitian diperoleh bahwa seluruh responden berpendidikan SLTA/sederajat sebanyak 9 orang (100\%). Berdasarkan lama kerja, sebagian besar responden bekerja $>8$ tahun sebanyak 5 orang $(55,6 \%)$, sebagian kecil bekerja $<8$ tahun sebanyak 4 orang $(44,4 \%)$. Berdasarkan hasil penelitian tentang tentang karakteristik responden dapat dilihat pada Tabel 1 berikut ini:

Tabel 1. Distribusi Frekuensi Berdasarkan Karakteristik Responden di Bagian Penyimpanan Rumah Sakit Umum Pusat H Adam Malik Tahun 2019

\begin{tabular}{|c|c|c|c|}
\hline No & Karakteristik & $\begin{array}{c}\text { Jumlah } \\
\text { (n) }\end{array}$ & $\begin{array}{c}\text { Persentase } \\
(\%)\end{array}$ \\
\hline \multirow[t]{3}{*}{1} & Umur & & \\
\hline & $>37$ tahun & 7 & 77,8 \\
\hline & $<37$ tahun & 2 & 22,2 \\
\hline \multirow[t]{3}{*}{2} & Jenis Kelamin & & \\
\hline & Laki-laki & 1 & 11,1 \\
\hline & Perempuan & 8 & 88,9 \\
\hline \multirow[t]{3}{*}{3} & Status Perkawinan & & \\
\hline & Belum Kawin & 1 & 11,1 \\
\hline & Kawin & 8 & 88,9 \\
\hline \multirow[t]{3}{*}{4} & Pendidikan & & \\
\hline & SLTA/Sederajat & 9 & 100,0 \\
\hline & Perguruan Tinggi & 0 & \\
\hline \multirow[t]{4}{*}{5} & Masa Kerja & & \\
\hline & $>8$ tahun & 5 & 55,6 \\
\hline & $<8$ tahun & 4 & 44,4 \\
\hline & Total & 9 & 100,0 \\
\hline
\end{tabular}

\section{Prosedur Sistem Penyimpanan}

Tugas-Tugas Yang Dilakukan Petugas Rekam Medis di Bagian Penyimpanan Berkas Rekam Medis RSUP H Adam Malik Tahun 2019

"Kami disini bekerja diruang penyimpanan saja dalam satu shift kerja yaitu sampai pukul 16.00 wib. Yang kami kerjakan mengambil berkas rekam medis sesuai nomor dan merapikan berkas yang ada di rak penyimpanan" (Informan 1 )

\footnotetext{
"Saya melakukan penyimpanan berkas sesuai dengan nomor dan disini mengunakan penjajaran terminal. Tugas yang lain, saya mengambil berkas rekam medis dari rak sesuai petunjuk rak jika ada pasien lama berobat lalu saya antar ke pendaftaran"'(Informan 2)
}

"Tugas saya antara lain mengambil berkas dari rak, menjajarkan berkas rekam medis sesuai penomoran dan menulis di buku peminjaman jika ada petugas kesehatan lain yang meminjam " (Informan 3)

"Saya melakukan penyimpan rekam medis jika pasien sudah pulang dengan menjajarkannya dengan rapi sesuai dengan urutan yang berlaku. Apabila ada pasien lama, saya meminta informasi pada petugas pendaftaran tentang nomor rekam medisnya. Dan juga bila waktunya kami disini melakukan retensi berkas untuk dibawa ke tempat penyimpanan in aktif" (Informan 4)

"Melakukan penyimpanan, pengambilan berkas, menyesuaikan penomoran dengan pasien dan membuat buku register " (Informan 5)

"Saya menyusun berkas jika terdapat penyusunan yang tidak rapi dan tidak pada tempatnya. Saya menulis buku peminjaman jika rekam medis dibawa dari rak penyimpanan untuk kepentingan pasien" (Informan 6)

"Tugas saya disini adalah menyimpan dan mengambil berkas, apabila dipinjam baru saya tulis di buku peminjaman. Jika waktunya saya juga mengerjakan retensi" (Informan 7)

"Tugas saya hanya menyimpan berkas jika sudah diantar ke ruang penyimpanan" (Informan 8)

"Kami disini bekerja mempunyai tugas masing-masing dan sudah dibagi oleh penanggung jawab bagian penyimpanan" (Informan 9)

Berdasarkan hasil wawancara tentang tugas-tugas yang dilakukan petugas rekam medis di bagian Penyimpanan Berkas Rekam Medis dapat disimpulkan bahwa beban kerja petugas sangat tinggi karena terdapatnya rangkap pekerjaan. 


\section{Hasil Wawancara Berdasarkan Sistem Penyimpanan Berkas Rekam Medis RSUP H Adam Malik Tahun 2019}

"Menurut saya, disini penyimpanannya semua rekam medis rawat jalan dan rawat inap di gabung satu map saja" (Informan 1)

"Menurut saya, dalam sistem penyimpanan sudah termasuk lokasi, bagaimana menjajarkan berkas, penomoran dan peminjaman berkas rekam medis" (Informan 2)

"Menurut saya, sistem penyimpanan berkas rekam medis sudah baik, ada petugas yang tetap di ruangan penyimpanan dan petugas penyimpanan yang bertugas khusus di ruangan penyimpanan sebanyak 9 orang" (Informan 3)

"Sistem penyimpanan yang ada disini sudah sesuai dengan standar yang ada. Namun pelaksanaannya yang perlu di awasi lagi agar petugas lebih teliti agar tidak terjadi salah letak atau penomoran ganda" (Informan 4)

"Sistem penyimpanan menurut saya sudah baik tetapi perlu pengawasan lagi agar lebih baik lagi kedepannya. Seharusnya ada diskusi setiap bulannya tentang penyelenggaraan rekam medis disini" (Informan 5)

"Sistem penyimpanan yang ada disini sudah komplek sesuai dengan kebutuhan yang ada. Akan tetapi terjadinya salah letak karena kurang tertatanya berkas di rak penyimpanan" (Informan 6)

"Sudah baik tetapi perlu dilengkapi lagi sesuai dengan kebutuhan yang ada" (Informan 7)

"Penyimpanan disini sudah menggunakan sistem yang baik” (Informan 8)

"Sistemnya sudah baik walaupun pelaksanaannya perlu di evaluasi kembali" (Informan 9)
Berdasarkan hasil wawancara tentang sistem penyimpanan berkas rekam medis, dapat disimpulkan bahwa sistem penyimpanan sudah baik dan sesuai dengan standar pelaksanaan penyimpanan tetapi perlu dilengkapi agar pelayanan lebih bermutu.

Prosedur Penyimpanan Berkas Rekam Medis RSUP H Adam Malik Tahun 2019

"Prosedur tentang penyimpanan sudah lengkap. Terkadang petugas tidak menjalankannya sesuai peraturan yang ada (Informan 1)

"Ketentuan yang ada disini bahwa penyimpanan berkas sudah ada tetapi perlu dilengkapi lagi. Masih terdapat berkas yang diletakkan tidak pada tempatnya" (Informan 2)

"Prosedur penyimpanan yang ada diantaranya prosedur penyimpanan, penjajaran, peminjaman, pengambilan berkas dan juga penomoran dan ini semua terkait dengan penyimpanan rekam medis secara keseluruhan" (Informan 3)

"Standar dalam penyimpanan sudah tertulis lengkap tetapi kurangnya sosialisasi dari kepala rekam medis terhadap petugas pelaksana dan mengakibatakan sering terjadi salah informasi” (Informan 4)

"Prosedur adalah berkas dari ruangan atau poliklinik rawat jalan terlebih dahulu diolah datanya baru dilakukan penyimpanan" (Informan 5)

"Aturan kerja kami disini sudah baik tetapi perlu perbaikan lagi kedepannya" (Informan 6)

"Setelah pasien pulang, berkas rekam medis pasien masuk ke bagian analisa data, setelah itu dilakukan klaim biaya untuk pasien bpjs lalu berkas tersebut disimpan" (Informan 7)

"Prosedur penyimpanan yang ada sudah cukup lengkap tetapi perlu dievaluasi kembali" (Informan 8) 
"Prosedur yang ada terkadang tidak sesuai dengan pelaksanaan di lapangan. Sering petugas bekerja diluar prosedur yang ada" (Informan 9)

Berdasarkan hasil wawancara tentang prosedur penyimpanan berkas rekam medis, dapat disimpulkan bahwa prosedur penyimpanan atau alur berkas rekam medis sudah tertulis lengkap tetapi kurangnya sosialisasi, pengawasan dan evaluasi dari panitia rekam medis terhadap petugas pelaksana mengakibatakan sering terjadi salah informasi.

\section{Fasilitas Dalam Pelaksanaan Penyimpanan Berkas Rekam Medis RSUP H Adam Malik Tahun 2019}

"Menurut saya belum sesuai harapan kami disini sebagai petugas penyimpanan" (Informan 1)

"Menurut saya rak penyimpanan masih kurang walaupun disini menggunakan rak terbuka tetapi jumlah pasien semakin bertambah" (Informan 2)

"Fasilitas penyimpanan terdapat tracer dan juga KIB yang tercetak langsung jika pasien datang berobat. Terdapat buku register dan KIUP di dalam komputer dan lain-lain" (Informan 3)

"Terdapat meja, tracer, KIUP, buku register, petunjuk rak, buku peminjaman, komputer, dll" (Informan 4)

"Di penyimpanan ada tracer, rak terbuka walau terbatas jumlahnya, ruangan kurang mencukupi untuk menampung berkas rekam medis" (Informan 5)

"Fasilitas untuk menunjang penyimpanan sudah mulai baik. Menurut saya hanya perlu penambahan ruangan dan rak penyimpanan saja" (Informan 6)

"Disini terdapat rak, ruangan tersendiri dekat dengan pendaftaran, adanya petugas yang tetap, sampul rekam medis sudah ada kode warna. Terdapat juga pendingin udara dan juga penerangan lampu yang menurut saya sudah sesuai kebutuhan" (Informan 7)

"Terutama ada rak, ruangan penyimpanan selain itu alat penunjang lainnya" (Informan 8)

"Perlu penambahan ruangan dan rak penyimpanan berkas rekam medis. Dilakukan retensi secara rutin agar rak tidak terlalu padat" (Informan 9).

Berdasarkan hasil wawancara tentang fasilitas dalam pelaksanaan penyimpanan berkas rekam medis, dapat disimpulkan bahwa perlu penambahan ruangan dan rak penyimpanan berkas rekam medis serta tangga dalam pengambilan berkas.

Kendala Petugas Dalam Pelaksanaan Penyimpanan Berkas Rekam Medis RSUP H Adam Malik Tahun 2019

"Kendalanya adalah kami kesulitan untuk melihat keberadaan berkas jika berkas rekam medisnya tidak ada didalam rak penyimpanan dan banyaknya berkas rekam medis yang menumpuk" (Informan 1)

"Kami petugas penyimpanan mangalami kesulitan jika berkas tidak ada di rak penyimpanan dan harus menghubung petugas kesehatan lainnya sedangkan pasien harus lama mengantri" (Informan 2)

"Sulit untuk mengambil berkas yang letaknya paling atas di rak penyimpanan dikarenakan tidak ada tangga" (Informan 3)

"Banyaknya kunjungan pasien sering menimbulkan tidak tertatanya berkas rekam medis di rak penyimpananan, ada yang bertumpuk pada suatu tempat" (Informan 4)

"Sering terjadi kesulitan apabila berkas tidak ada di rak, sehingga terjadi penomoran ganda karena petugas tidak tau keberadaan rekam medis pasien" (Informan 5)

"Saya kesulitan mengambil berkas rekam medis karena terjadi kesalahan letak dari petugas penyimpanan lainnya" (Informan 6)

"Sering terjadi bahwa berkas rekam medis hanya ditumpuk saja di ruangan tanpa disimpan lagi di rak" (Informan 7) 
"Terjadi kesalahan letak berkas rekam medis karena tidak tertata dengan rapi di rak penyimpanan" (Informan 8 )

"Kendala yang saya alami berkas rekam medis ada yang tidak terletak di rak tetapi masih di ruang perawatan atau pada bagian pengklaiman” (Informan 9)

Berdasarkan hasil wawancara tentang kendala petugas dalam pelaksana penyimpanan berkas rekam medis, dapat disimpulkan bahwasannya sering terjadi kesalahan letak berkas rekam medis karena tidak tertata dengan rapi di rak penyimpanan. Waktu dalam pengembalian berkas rekam medis rawat jalan dan rawat inap ke ruang penyimpanan tidak sesuai dengan standar yang ada dimana terdapat berkas yang masih berada di unit lain sebelum dikembalikan pada ruang penyimpanan.

\section{Hasil Fasilitas Sistem Penyimpanan Berkas Rekam Medis}

Tabel 2. Hasil Observasi Sistem Penyimpanan Berkas rekam Medis Di Rumah Sakit Umum Pusat H Adam Malik Tahun 2019

\begin{tabular}{|c|c|c|c|c|}
\hline No & Observasi & Ada & Tidak Ada & Keterangan \\
\hline 1 & $\begin{array}{l}\text { Prosedur penyimpanan } \\
\text { berkas rekam medis }\end{array}$ & $\sqrt{ }$ & & $\begin{array}{l}\text { Prosedur penyimpanan tersedia tetapi kurang } \\
\text { lengkap }\end{array}$ \\
\hline 2 & $\begin{array}{l}\text { Prosedur penjajaran berkas } \\
\text { rekam medis }\end{array}$ & $\sqrt{ }$ & & $\begin{array}{l}\text { Prosedur penyimpanan tersedia tetapi kurang } \\
\text { lengkap }\end{array}$ \\
\hline 3 & $\begin{array}{l}\text { Prosedur peminjaman } \\
\text { berkas rekam medis }\end{array}$ & $\sqrt{ }$ & & $\begin{array}{l}\text { Prosedur penyimpanan tersedia tetapi kurang } \\
\text { lengkap }\end{array}$ \\
\hline 4 & $\begin{array}{l}\text { Prosedur pengambilan } \\
\text { berkas rekam medis }\end{array}$ & $\sqrt{ }$ & & $\begin{array}{l}\text { Prosedur penyimpanan tersedia tetapi kurang } \\
\text { lengkap }\end{array}$ \\
\hline 5 & $\begin{array}{l}\text { Prosedur penomoran } \\
\text { berkas rekam medis }\end{array}$ & $\sqrt{ }$ & & $\begin{array}{l}\text { Prosedur penyimpanan tersedia tetapi kurang } \\
\text { lengkap }\end{array}$ \\
\hline 6 & Tracer & $\sqrt{ }$ & & $\begin{array}{l}\text { Tracer tersedia dan dicetak langsung dari } \\
\text { komputerisasi }\end{array}$ \\
\hline 7 & KIUP & $\sqrt{ }$ & & KIUP tersedia secara komputerisasi \\
\hline 8 & Berkas rekam medis & $\sqrt{ }$ & & $\begin{array}{l}\text { Tersedia berkas rekam medis sesuai standar } \\
\text { yang ada }\end{array}$ \\
\hline 9 & Ruang penyimpanan & $\sqrt{ }$ & & $\begin{array}{l}\text { Ruang penyimpanan ada tetapi kurang } \\
\text { mencukupi }\end{array}$ \\
\hline 10 & Rak penyimpanan berkas & $\sqrt{ }$ & & $\begin{array}{l}\text { Rak penyimpanan ada dengan jenis terbuka } \\
\text { sebanyak } 70 \text { buah dimana dalam } 1 \text { rak terdapat } \\
1000 \text { berkas. }\end{array}$ \\
\hline 11 & Tangga untuk penyimpanan & & $\sqrt{ }$ & $\begin{array}{l}\text { Tidak tersedia tangga untuk pengambilan berkas } \\
\text { rekam medis }\end{array}$ \\
\hline 12 & Pendingin Udara & $\sqrt{ }$ & & Tersedia AC dengan Suhu ruangan $18-28^{\circ} \mathrm{C}$ \\
\hline 13 & Penerangan & $\sqrt{ }$ & & Pencahayaan sesuai standar yaitu 100 lux \\
\hline
\end{tabular}

Berdasarkan tabel 2 tentang obervasi sistem penyimpanan berkas rekam medis, dapat disimpulkan bahwasannya terdapat $92,3 \%$ fasilitas sudah memadai dan $7,7 \%$ tidak memadai yaitu tidak tersedianya tangga untuk pengambilan berkas rekam medis.

\section{PEMBAHASAN}

Prosedur penyimpanan berkas rekam medis

Dari hasil penelitian menunjukkan bahwa terdapat Standar Prosedur Operasional (SPO) penyimpanan, penjajaran, peminjaman, pengambilan berkas dan penomoran rekam medis. Prosedur pelaksanaan penyimpanan maupun alur berkas rekam medis sudah tertulis dengan lengkap tetapi kurangnya sosialisasi 
dari panitia rekam medis terhadap petugas pelaksana mengakibatkan sering terjadi salah informasi (Informan IV) dan prosedur terkadang tidak sesuai dengan pelaksanaan di lapangan, sering kali petugas bekerja diluar prosedur yang ada (Informan IX). Pengawasan yang kurang dari atasan mengakibatkan terjadinya salah letak atau penomoran ganda. Perlu evaluasi kembali tentang pelaksanaan penyimpanan berkas rekam medis secara berkelanjutan agar menjadi lebih baik lagi.

Diketahui juga bahwa Sistem penomoran rekam medis di RSUP $\mathrm{H}$ adam Malik menggunakan Unit Numbering System, penyimpanan lokasi secara Sentralisasi dan penjajaran Terminal Digit Filling System dimana sistem ini lebih dianjurkan secara teori yang ada karena lebih efektif dan efisien. Terdapat petugas penyimpanan sebanyak 9 orang yang melakukan pelaksanaan penyimpanan berkas rekam medis dengan pendidikan SLTA/sederajat. Hal ini mengakibatkan kurangnya pengetahuan petugas dalam melakukan penyimpanan karena kurang kompeten dilihat dari pendidikannya.

Dalam mengidentifikasi masalah yang menjadi permasalahan pada posedur penyimpanan berkas rekam medis ada beberapa hal yang perlu diperhatikan seperti lebih memahami prosedur yang sudah ada, untuk itu seharusnya dilakukan sosialisasi dan pengawasan dari panitia rekam medis dan petugas pelaksana harus melakukan tugas-tugasnya sesuai prosedur yang ada agar tugas-tugas tesebut berjalan dengan lancar. Diharapkan waktu dalam pengembalian berkas rekam medis dari poliklinik dan ruangan harus tepat waktu sesuai dengan standar yang ada.

Prosedur merupakan tata cara, aturan dan pedoman dalam pelaksanaan suatu pekerjaan. Prosedur adalah pengembangan dari standarisasi profesi dan kebijakankebijakan yang telah ditetapkan sebelumnya, baik berupa undang-undang, peraturan menteri, standar pelayanan miminimal dan lain-lain. Setiap rumah sakit memiliki prosedur penyimpanan berkas rekam medis yang berbeda disesuaikan dengan kebutuhan pelayananannya. Saat ini acuan dalam prosedur penyimpanan terdapat dalam Standar Nasional Akreditasi Rumah Sakit (SNARS) yang mulai berlaku pada tahun 2019 dimana sebelumnya berpedoman pada KARS (2012).

Menurut asumsi peneliti bahwa jika prosedur sudah lengkap tetapi petugas penyimpanan tidak melaksanakannya dengan baik, dapat menimbulkan masalah yang besar. Sering terjadi kesalahan dalam pelaksanaan tugas dikarenakan acuan tidak seragam. Hal yang paling fatal adalah terjadinya sengketa medik atau kasus yang dapat berujung ke pengadilan akibat dari pelaksanaan penyimpanan tidak sesuai dengan aturan yang ada. Karena prosedur penyimpanan berhubungan erat dengan kerahasiaan medis, dimana sesuatu yang mutlak dilindungi dari orang yang tidak berkepentingan. Sesuai dengan Undangundang No 29 tahun 2004, tentang praktik kedokteran disebutkan bahwa Isi rekam medis merupakan milik pasien sedangkan berkasnya adalah milik faskes yaitu RSUP $\mathrm{H}$ Adam Malik Medan.

\section{Fasilitas Penyimpanan Berkas Rekam Medis}

Dari hasil penelitian di RSUP H Adam Malik, fasilitas penyimpanan rekam medis mencakup perlengkapan yang digunakan untuk menyimpan rekam medis maupun peralatan penyimpanan yang berhubungan dengan berkas rekam medis pasien yang akan disimpan. Fasilitas-fasitas tersebut menunjukkan bahwa bahwasannya terdapat 92,3\% fasilitas sudah memadai dan 7,7\% tidak memadai yaitu tidak tersedianya tangga untuk pengambilan berkas rekam medis. Selanjutnya dari observasi yang dilakukan oleh peneliti, rak dan ruangan penyimpanan kurang mencukupi untuk menampung berkas rekam medis yang ada.

Menurut pendapat (Hatta, 2014), fasilitas dan bentuk fisik ruangan penyimpanan rekam medis harus mencakup ruangan dan peralatan yang cukup menyimpan rekam medis sehingga mudah diambil jika diperlukan kembali. Efesiensinya penggunaan peralatan dan kondisi keamanan diruangan penyimpanan 
akan membantu produktivitas petugas dalam penyimpanan.

Menurut (Depkes, 2006), peraturan ruang penyimpanan berkas rekam medis yaitu: ruang hendaknya terhindar dari bahan yang dapat merusak berkas rekam medis, ruang penyimpanan rekam medis hendaknya dibuat jarak atau tembok dari ruang kantor lain mengingat bahwa berkas rekam medis sifatnya rahasia, mengurangi dan menghindari pegawai lain memasuki ruangan sehingga kehilangan berkas rekam medis dapat dihindari.

Sesuai dengan pendapat (Rustiyanto, 2014), pada sistem penyimpanan dibutuhkan alat penyimpanan yang baik, penerangan yang baik, pengaturan suhu dan pemeliharaan ruangan. Faktor keselamatan kerja petugas penting untuk dijadikan perhatian dalam ruang penyimpanan rekam medis sehingga dapat membantu memelihara dan mendorong semangat kerja serta dapat meningkatkan produktivitas petugas yang bekerja di bagian ruangan penyimpanan.

Alat penyimpanan rekam medis yang umum dipakai adalah Rak terbuka (open self file unit), Lemari lima laci (five - drawer file cabinet) dan Roll O'pack (terdiri dari rak file statis dan dinamis). Jarak antara dua buah rak untuk lalu lalang, dianjurkan selebar $90 \mathrm{~cm}$, jika menggunakan lemari lima laci satu baris, ruangan lowong di depannya harus $90 \mathrm{~cm}$. Jika diletakkan saling berhadapan harus disediakan ruang lowong paling tidak $150 \mathrm{~cm}$ untuk memungkinkan terbuka laci-laci tersebut.

Tempat penyimpanan berkas rekam medis harus di jaga ke lembabannya supaya tetap kering. Agae ruangan tidak terlalu lembab perlu diatur suhu udara berkisar $18^{\circ} \mathrm{C}$ sampai $23^{\circ} \mathrm{C}$ dan kelembaban udara sekitar 50\% sampai $65 \%$. Untuk dihidupkan selama 24 jam terus menerus (KARS, 2012).

Menurut asumsi peneliti bahwa dengan bertambahnya jumlah pasien tanpa disertai perencanaaan pembangunan ruangan dan rak penyimpananan dapat menimbulkan masalah penumpukan berkas sehingga menyulitkan petugas mencari berkas apabila pasien datang berobat kembali ke rumah sakit. Tidak tersedianya tangga sebagai alat dalam mengambil berkas yang ada di rak penyimpanan mengakibatkan petugas mengalami kesulitan dalam mengambil berkas rekam medis sehingga sering terjadi salah letak dan penomoran ganda.

\section{KESIMPULAN}

Berdasarkan hasil penelitian dan pembahasan yang telah diuraikan sebelumnya, maka dapat diambil beberapa kesimpulan sebagai berikut :

1. Petugas penyimpan rekam medis semuanya lulusan SLTA, walaupun tidak ada tamatan rekam medisnya ruang penyimpanannya berjalan dengan baik karena sudah ICI.

2. Prosedur penyimpanan berkas rekam medis yang dilakukan di RSUP H Adam Malik sudah baik tetapi kurangnya sosialisasi dari kepala rekam medis terhadap petugas pelaksana dan mengakibatkan sering terjadi salah informasi

3. Fasilitas dan sarana yang terdapat di ruang penyimpanan rekam medis di RSUP H Adam Malik hampir memenuhi standar, terdapat $92,3 \%$ fasilitas sudah memadai dan $7,7 \%$ tidak memadai yaitu kurang pedulinya petugas terhadap berkas rekam medis sehingga banyak berkas yang basah dan kotor.

\section{SARAN}

1. Bagi Rumah sakit

Diharapkan bagi rumah sakit untuk melakukan pelatihan kepada petugas rekam medis dan perencanaan ruangan penyimpanan karena kunjungan ketersediaan sarana dan prasarana serta fasilitas penyimpanan berkas rekam medis.

2. Bagi Institut

Agar menjadi bahan referensi untuk meningkatkan penyelenggaraan pendidikan perekam dan informasi kesehatan yaitu dalam sistem penyimpanan berkas rekam medis di rumah sakit. 
3. Bagi Mahasiswa

Diharapkan untuk melakukan penelitian selanjutnya dengan jenis penelitian kuantitatif tentang mengukur rak penyimpanan rekam medis, jarak ruangan penyimpanan rekam medis, suhu ruangan rekam medis dan sebagainya.

\section{DAFTAR PUSTAKA}

Budi, S C. (2011). Manajemen Unit Kerja Rekam Medis. Jogjakarta: Quantum Sinergis Media.

Departemen Kesehatan RI. (2006). Pedoman Penyelenggaraan dan Prosedur Rekam Medis Rumah Sakit. Jakarta: Direktorat Jendral Pelayanan Medik

Departemen Kesehatan RI. (2009). Undang-Undang No. 44 tahun 2009 tentang Rumah Sakit. Jakarta: Depkes RI

Hatta, Gemala R. (2011). Pedoman Manajemen Informasi Kesehatan di Sarana Pelayanan Kesehatan. Jakarta: UI-Press.

Huffman, Edna K. (1994). Health Information Management, Physician Record Company, Berwyn, Illinois.

Kemenkes RI . (2008). Keputusan Menteri Kesehatan Republik Indonesia Nomor. 129/Menkes SK/II/2008 Tentang
Standar Pelayanan Minimal Rumah Sakit. Jakarta: Kemenkes RI.

Menteri Kesehatan Republik Indonesia. (2008). Permenkes Nomor 269/MENKES/PER/III/2008. Jakarta: Menkes RI.

Menteri Kesehatan Republik Indonesia. (2013). Peraturan Menteri Kesehatan Nomor 55/PER/MENKES/2013 tentang Penyelenggaraan Pekerjaan Rekam Medis. Jakarta: Mentrian Kesehatan Republik Indonesia.

Notoadmodjo, S. (2010). Kesehatan Masyarakat Ilmu \& Seni. Jakarta: Rineka Cipta.

Rustiyanto, E dan Rahayu. W. A. (2011). Manajemen Filing Dokumen Rekam Medis dan Informasi Kesehatan. Yogyakarta: Permata Indonesia.

Rustiyanto, Ery. (2009). Etika Profesi: Perekam Medis dan Informasi Kesehatan. Edisi Pertama. Yogyakarta: Graha Ilmu.

Sugiyono. (2013). Metode Penelitian Pendidkan Pendekatan Kuantitatif, Kualitatif. Bandung: Alfabeta.

UU RI. (2004). Undang- Undang Republik Indonesia No. 29 Tahun 2004 Tentang Praktek Kedokteran. Jakarta: UU RI.

UU RI. (2009). Undang- Undang Republik Indonesia Nomor 44 Tahun 2009 Tentang Rumah sakit. Jakarta: UU RI. 